\title{
Efektifitas Pijat Oksitosin Dan Pijat Payudara Terhadap Produksi ASI Pada Ibu Postpartum
}

\author{
Asirotul Ma'rifah', Naning Puji Suryantini ${ }^{2 *}$ \\ 1, 2 STIKES Bina Sehat PPNI Mojokerto \\ *email: naningpujisuryantini@yahoo.com
}

\begin{abstract}
Breast milk is indeed important for newborns, but the problem faced by breastfeeding mothers is the lack of milk production. Every woman's body is different in producing milk, some produce a lot of milk, and some also produce little milk on the first day or even a few weeks later. Decreased milk production during early breastfeeding is a problem for mothers to breastfeed their babies from an early age. Non-pharmacological alternative treatments to increase milk production are oxytocin massage and breast massage intervention. This study analyzed the effectiveness of postpartum mother's milk production in the group given the intervention of Oxytocin Massage and Breast Massage with the control group. This study was an experimental study with a pretest-posttest control group design that used the Consecutive Sampling technique, the number of respondents in this study amounted to 20 people, the analysis technique used the Wilcoxon sign test with SPSS. The results showed that there was an effect of oxytocin massage on postpartum milk production $=$ 0.000 , and there was an effect of breast massage on postpartum milk production $=0.000$. There was no difference in the effect of oxytocin massage and breast massage on the production of postpartum mother's milk $=0.893$. The conclusions of this study are: $(1)$ oxytocin massage can increase the production of postpartum mothers; (2) breast massage increases postpartum maternal production; (3) There is no difference in the effect of oxytocin massage and breast massage in increasing postpartum maternal output in Al-Hikmah RB, Mojokerto Regency.
\end{abstract}

Keywords: Breast milk production; Oxytocin massage; Breast massage.

\begin{abstract}
Abstrak
ASI memang penting untuk bayi baru lahir, namun masalah yang dihadapi ibu menyusui adalah kurangnya produksi ASI. Setiap tubuh wanita berbeda dalam memproduksi ASI, ada yang banyak menghasilkan susu, dan ada juga yang produksi ASInya sedikit pada hari pertama bahkan beberapa minggu kemudian. Penurunan produksi ASI saat pemberian ASI dini merupakan masalah bagi ibu untuk menyusui bayinya sejak dini. Pengobatan alternatif non farmakologis untuk meningkatkan produksi ASI adalah dengan pijat oksitosin dan intervensi pijat payudara. Penelitian ini menganalisis efektifitas produksi ASI ibu postpartum pada kelompok yang diberikan intervensi Oxytocin Massage dan Breast Massage dengan kelompok kontrol. Penelitian ini merupakan penelitian eksperimental dengan desain pretest-posttest control group design. Dengan menggunakan teknik Consecutive Sampling, responden penelitian ini berjumlah 20 orang, teknik analisis menggunakan uji tanda Wilcoxon dengan spss. Hasil penelitian menunjukkan adanya pengaruh pijat oksitosin terhadap produksi ASI postpartum $\rho=0,000$, dan ada pengaruh pijat payudara terhadap produksi ASI postpartum $\rho=0,000$. Tidak ada perbedaan pengaruh antara pijat oksitosin dan pijat payudara terhadap produksi ASI ibu nifas $\rho=0.893$. Kesimpulan dari penelitian ini adalah: (1) pijat oksitosin dapat meningkatkan produksi ibu nifas; (2) pijat payudara meningkatkan produksi ibu nifas; (3) Tidak ada perbedaan pengaruh antara pijat oksitosin dan pijat payudara dalam meningkatkan output ibu nifas di RB Al-Hikmah Kabupaten Mojokerto.

Kata kunci: Produksi ASI, Pijat Oksitosin; Pijat Payudara.
\end{abstract}




\section{Pendahuluan}

Menyusui tidak hanya memberikan ASI pada bayi. Lebih dari itu, terdapat kedekatan batin dan emosional antara ibu dan bayi, yang sangat penting untuk perkembangan mental bayi agar tumbuh menjadi pribadi yang percaya diri. Oleh karena itu, bayi yang baru lahir sampai usia minimal 6 bulan harus mendapat ASI eksklusif, seperti yang dikatakan oleh pakar pangan dan gizi, Dr. FG. Winarno.[1] Namun, meski ASI penting bagi bayi baru lahir, masalah ibu menyusui adalah kurangnya produksi ASI. Setiap tubuh wanita berbeda dalam memproduksi ASI, ada yang melimpah ASI, ada yang sedikit produksi ASI pada hari pertama bahkan beberapa minggu setelahnya.

Faktor yang mempengaruhi produksi dan pengeluaran ASI. Produksi ASI dikendalikan oleh hormon prolaktin, sedangkan hormon oksitosin mempengaruhi produksi. Hormon oksitosin akan keluar melalui rangsangan ke puting susu melalui hisapan mulut bayi atau pijatan pada tulang belakang ibu bayi; dengan pijatan pada rentang tersebut, ibu akan merasa tenang, rileks, meningkatkan ambang rasa sakit dan menyayangi bayinya sehingga hormon oksitosin keluar. ASI cepat keluar.[2]

Di dunia, prevalensi menyusui masih sangat rendah. Beberapa penelitian menemukan bahwa sebagian besar menyusui kurang pengetahuan dan informasi yang tidak benar dan tidak konsisten. Di Kamboja, 74\% menyusui untuk bayi di bawah 6 bulan, Tunisia turun drastis dalam menyusui hanya 6,2\% pada akhir dekade ini.[3] Begitu pula di Indonesia, data dari Pusat Laktasi Indonesia mencatat berdasarkan SDKI (2010), bahwa hanya 48\% ibu menyusui bayi usia 0-6 bulan. Wilayah Jawa Timur dalam pemberian ASI adalah 34,5\% dari 57.208 (laporan tahunan Promkes 2009).[4]

Berdasarkan Studi Awal di RB Al-Hikmah Ny. Suharti, SST. Kabupaten Mojokerto, 33 ibu memiliki bayi usia 0-6 bulan, 12 ibu yang berkunjung pada tanggal 20-25 April 2020. Setelah peneliti melakukan wawancara dengan 12 ibu yang melihat RB, ditemukan 4 ibu yang memiliki bayi usia 0-6 tahun. bulan menyatakan ASI keluar lancar, sedangkan 8 ibu yang memiliki bayi usia 0-6 bulan mengatakan ASI yang keluar sedikit. Tidak semua ibu nifas memerah ASI dengan segera karena pelepasan ASI merupakan interaksi yang sangat kompleks antara rangsangan mekanis, saraf, dan berbagai hormon yang mempengaruhi sekresi oksitosin. Selain dipengaruhi oleh isapan bayi, pelepasan hormon oksitosin juga dikendalikan oleh reseptor sistem duktal. Ketika duktus melebar atau menjadi lunak, maka secara elektrik oksitosin dilepaskan oleh hipofisis, yang berperan dalam memeras susu dari alveoli.[5] Oleh karena itu, perlu dilakukan pemerasan ASI bagi sebagian ibu nifas.

Pijat atau stimulasi tulang belakang, neurotransmitter akan merangsang medula oblongata untuk mengirim pesan langsung ke hipotalamus di hipofisis posterior untuk melepaskan oksitosin, menyebabkan payudara mengeluarkan ASI. Pijat di area tulang belakang juga akan mengendurkan ketegangan dan menghilangkan stres. Sehingga hormon oksitosin dilepaskan dan akan membantu keluarnya ASI, dibantu dengan hisapan bayi pada puting susu segera setelah bayi lahir dengan bayi normal. [6]

Pijat merupakan salah satu solusi untuk mengatasi produksi ASI yang tidak senonoh. Pijat adalah pijatan di sepanjang tulang belakang (vertebrae) sampai ke 
tulang rusuk kelima-keenam dan merupakan cara untuk merangsang hormon prolaktin dan oksitosin setelah melahirkan. [7] Pijat payudara bermanfaat bagi ibu menyusui yang menginginkan ASI dikeluarkan dengan lancar. Pijat payudara dapat membersihkan saluran ASI sehingga ASI mengalir lebih lancar dan mengosongkan payudara, yang merangsang ASI lebih banyak. Pijatan ini berfungsi untuk meningkatkan hormon oksitosin yang dapat menenangkan ibu untuk keluar secara otomatis.

\section{Metode}

Desain penelitian ini analitik dengan desain pra eksperimen menggunakan desain control group pretest-posttest. Populasi penelitian ini adalah seluruh ibu nifas di RB AlHikmah Kabupaten Mojokerto yang berjumlah 32 responden. Pengambilan sampel menggunakan Consecutive Sampling. Jadi sampel yang didapat adalah 20 orang.

Variabel bebas adalah Pijat Oksitosin dan Pijat Payudara. Sedangkan variabel terikatnya adalah produksi susu. Instrumen yang digunakan untuk variabel pijat oksitosin dan pijat payudara adalah SOP, dan instrumen produksi berupa lembar observasi dan angket. Teknik analisis data menggunakan uji tanda wilcoxon dengan SPSS nilai $p<0,05$.

\section{Hasil dan Pembahasan}

Hasil

Tabel 1. Distribusi responden menurut umur

\begin{tabular}{ccll}
\hline \multirow{2}{*}{ No. } & \multirow{2}{*}{ Usia } & \multicolumn{2}{c}{ Kelompok } \\
\cline { 3 - 4 } & & Intervensi & Kontrol \\
\cline { 3 - 4 } & & $\mathbf{N}(\%)$ & $\mathbf{N}(\%)$ \\
\hline 1 & $<30$ years & $7(70)$ & $6(60)$ \\
2 & $>30$ years & $3(30)$ & $4(40)$ \\
\hline \multirow{2}{*}{ tal $^{\text {ta }}$} & $10(100)$ & $10(100)$ \\
\hline
\end{tabular}

Responden pada kelompok Intervensi sebanyak 7 responden (35\%) dengan indikasi usia $<30$ tahun, dan sebanyak 6 responden $(30 \%)$ pada kelompok kontrol dengan indikasi usia $<30$ tahun.

Tabel 2 Karakteristik berdasarkan Paritas, Profesi dan Pendidikan

\begin{tabular}{|c|c|c|c|c|c|}
\hline \multirow[b]{2}{*}{ No. } & \multirow{2}{*}{\multicolumn{2}{|c|}{ Variabel }} & \multicolumn{2}{|l|}{ Kelompok } & \multirow{3}{*}{$\rho$ Value } \\
\hline & & & Intervensi & Kontrol & \\
\hline \multirow{3}{*}{1} & \multirow{3}{*}{ Paritas } & & & & \\
\hline & & Primipara & $4(40)$ & $3(30)$ & 0,582 \\
\hline & & Multipara & $6(60)$ & $7(70)$ & \\
\hline \multirow[t]{2}{*}{2} & \multirow{2}{*}{ Pekerjaan } & Bekerja & $2(20)$ & $5(50)$ & 0,166 \\
\hline & & $\begin{array}{l}\text { Tidak } \\
\text { bekerja }\end{array}$ & $8(80)$ & $5(50)$ & \\
\hline \multirow[t]{2}{*}{3} & Pendidikan & Rendah & $7(70)$ & $6(60)$ & 1,000 \\
\hline & & Tinggi & $3(30)$ & $4(40)$ & \\
\hline
\end{tabular}

*alpha $=0,05$ 
Tabel di atas menunjukkan bahwa paritas pada kelompok intervensi adalah $6(60 \%)$, dan pada kelompok kontrol sebagian besar ibu nifas multipara yaitu 7 (70\%). Dari segi pekerjaan, $8(80 \%)$ ibu nifas pada kelompok intervensi tidak bekerja, dan $5(50 \%)$ pada kelompok kontrol. Sebagian besar ibu nifas pada kelompok intervensi sebanyak $7(70 \%)$ berpendidikan rendah. Pada kelompok kontrol, ibu juga berpendidikan rendah sebanyak 6 $(60 \%)$.

Tabel 3 Distribusi Frekuensi ibu nifas berdasarkan produksi ASI di RB Al-Hikmah Kabupaten Mojokerto ( $\mathrm{N}=20)$

\begin{tabular}{|c|c|c|c|c|c|c|}
\hline \multirow{3}{*}{ Pengukuran } & \multirow{3}{*}{ Kelompok } & \multicolumn{4}{|c|}{ Produksi ASI } & \multirow{3}{*}{$\rho$ Value } \\
\hline & & \multicolumn{2}{|c|}{ Lancar } & \multicolumn{2}{|c|}{ Tidak Lancar } & \\
\hline & & $\mathbf{n}$ & $\%$ & $\mathbf{n}$ & $\%$ & \\
\hline \multirow[t]{2}{*}{ I } & Intervensi & 7 & 70 & 3 & 30 & 0,045 \\
\hline & Kontrol & 4 & 40 & 6 & 60 & \\
\hline \multirow[t]{2}{*}{ II } & Intervensi & 8 & 80 & 2 & 20 & 0,005 \\
\hline & Kontrol & 5 & 50 & 5 & 50 & \\
\hline \multirow[t]{2}{*}{ III } & Intervensi & 9 & 90 & 1 & 10 & 0,000 \\
\hline & Kontrol & 3 & 30 & 7 & 70 & \\
\hline
\end{tabular}

$\mathrm{p}=0,05$

Berdasarkan tabel 3 menunjukkan hasil analisis efektifitas pijat oksitosin dan pijat payudara terhadap produksi ASI ibu Post Patum menunjukkan bahwa 7 responden (70\%) yang pernah diberikan kombinasi teknik pijat oksitosin. dan pijat payudara halus. Namun hanya 4 responden (40\%) yang memperoleh hasil produksi susu lancar (Kelompok Kontrol). Hasil uji statistik diperoleh nilai $\rho$ value $=0,045$ yang berarti terdapat perbedaan produksi susu antara kelompok intervensi dan kelompok kontrol.

Tabel 4 Distribusi Frekuensi Ibu Nifas Menurut Umur, Pendidik, dan Pekerjaan Produksi ASI pada Kelompok Intervensi di BPR Al-Hikmah Kabupaten Mojokerto ( $=10)$

\begin{tabular}{|c|c|c|c|c|c|c|c|}
\hline \multirow{3}{*}{ Variabel } & \multirow{3}{*}{ Kategori } & \multicolumn{4}{|c|}{ Produksi ASI } & \multirow{3}{*}{ OR 95\% CI } & \multirow{3}{*}{$\rho$ Value } \\
\hline & & \multicolumn{2}{|c|}{ Lancar } & \multicolumn{2}{|c|}{$\begin{array}{l}\text { Tidak } \\
\text { Lancar }\end{array}$} & & \\
\hline & & $\mathbf{n}$ & $\%$ & $\mathrm{n}$ & $\%$ & & \\
\hline \multirow[t]{2}{*}{ Usia } & $<30$ & 6 & 86 & 1 & 14 & 0,364 & 0,599 \\
\hline & $>30$ & 2 & 67 & 1 & 33 & $(0,248-30,512)$ & \\
\hline \multirow[t]{2}{*}{ Pendidikan } & Rendah & 6 & 86 & 1 & 14 & 0,625 & 1,000 \\
\hline & Tinggi & 1 & 33 & 2 & 67 & $(0,142-18.00)$ & \\
\hline \multirow{2}{*}{ Pekerjaan } & Bekerja & 1 & 50 & 1 & 50 & 0,353 & 0,558 \\
\hline & $\begin{array}{c}\text { Tidak } \\
\text { Bekerja }\end{array}$ & 7 & 88 & 1 & 12 & $(0,324-24,808)$ & \\
\hline \multirow[t]{2}{*}{ Paritas } & Primipara & 3 & 75 & 1 & 25 & 0,917 & 1,000 \\
\hline & Multipara & 5 & 83 & 1 & 17 & $(0,130-9,124)$ & \\
\hline
\end{tabular}

Berdasarkan tabel 3 menunjukkan hasil analisis efektifitas pijat oksitosin dan pijat payudara terhadap produksi ASI ibu Post Patum menunjukkan bahwa 7 responden (70\%) yang pernah diberikan kombinasi teknik pijat oksitosin. dan pijat payudara halus. Namun 
hanya 4 responden (40\%) yang memperoleh hasil produksi susu lancar (Kelompok Kontrol). Hasil uji statistik diperoleh nilai $\rho$ value $=0,045$ yang berarti terdapat perbedaan produksi susu antara kelompok intervensi dan kelompok kontrol.

Tabel 5 Distribusi Frekuensi Ibu Post Partum Menurut Umur, Pendidikan, dan Pekerjaan Produksi ASI pada Kelompok Kontrol di RB Al-Hikmah Kabupaten Mojokerto ( $\mathrm{N}=10$ )

\begin{tabular}{|c|c|c|c|c|c|c|c|}
\hline \multirow{3}{*}{ Variabel } & \multirow{3}{*}{ Kategori } & \multicolumn{4}{|c|}{ Produksi ASI } & \multirow{3}{*}{ Variabel } & \multirow{3}{*}{$\rho$ Value } \\
\hline & & \multicolumn{2}{|c|}{ Lancar } & \multicolumn{2}{|c|}{ Tidak Lancar } & & \\
\hline & & $\mathrm{n}$ & $\%$ & $\mathbf{n}$ & $\%$ & & \\
\hline \multirow[t]{2}{*}{ Usia } & $<30$ & 1 & 17 & 5 & 83 & \multirow{2}{*}{$\begin{array}{c}0,177 \\
(0,656- \\
62,400)\end{array}$} & \multirow[t]{2}{*}{0,193} \\
\hline & $>30$ & 2 & 50 & 2 & 50 & & \\
\hline \multirow[t]{2}{*}{ pendidikan } & Rendah & 2 & 33 & 4 & 67 & \multirow{2}{*}{$\begin{array}{c}0,625 \\
(0,310-8,247)\end{array}$} & \multirow[t]{2}{*}{0,683} \\
\hline & Timggi & 1 & 25 & 3 & 75 & & \\
\hline \multirow{2}{*}{ Pekerjaan } & Bekerja & 1 & 20 & 4 & 80 & \multirow{2}{*}{$\begin{array}{c}0,640 \\
(0,312-7,819)\end{array}$} & \multirow[t]{2}{*}{0,695} \\
\hline & $\begin{array}{l}\text { Tidak } \\
\text { Bekerja }\end{array}$ & 2 & 40 & 3 & 60 & & \\
\hline \multirow[t]{2}{*}{ Paritas } & Primipara & 1 & 33 & 2 & 67 & 0,786 & \multirow[t]{2}{*}{1,00} \\
\hline & Multipara & 3 & 43 & 4 & 57 & $(0,237-6,821)$ & \\
\hline
\end{tabular}

Data tersebut menunjukkan bahwa 1 orang $(17 \%)$ ibu nifas usia $<30$ tahun yang produksi ASI lancar, sedangkan 2 orang ( $>30$ tahun) yang produksi ASI lancar sebanyak 2 orang $(50 \%)$. Hasil analisis yang berbeda menunjukkan tidak ada perbedaan produksi ASI pada ibu nifas yang berusia $<30$ tahun dan ibu nifas $>30$ tahun dengan $\rho$ Value $=0,177$. Hasil ini menunjukkan bahwa tidak ada pengaruh usia terhadap produksi ibu nifas pada kelompok kontrol.

\section{Pembahasan}

Penelitian ini mengevaluasi efektivitas pijat oksitosin dan pijat payudara terhadap produksi ASI ibu postpartum. Hasil penelitian menunjukkan bahwa pada kelompok intervensi (diberikan intervensi gabungan pijat oksitosin dan pijat payudara), produksi ASI lancar. Jumlah tersebut lebih besar dari proporsi produksi ASI ibu nifas yang tidak lancar. Disimpulkan bahwa terdapat perbedaan rasio produksi susu lancar antara kelompok intervensi dan kelompok kontrol dengan $\mathrm{p}$-value $=0,000$ pada pengukuran terakhir. Sebaliknya nilai OR $=11.500$ yang berarti ibu nifas yang diberikan pijat kombinasi intervensi oksitosin dan pijat payudara berpeluang 11,5 kali lebih besar untuk melancarkan produksi ASI dibandingkan kelompok kontrol. Hasil penelitian ini menjelaskan bahwa hipotesis utama peneliti terbukti, artinya kombinasi intervensi pijat oksitosin dan pijat payudara efektif dalam meningkatkan produksi ASI ibu nifas.

Fenomena yang ditemukan di lapangan menunjukkan bahwa produksi ASI dan rendahnya pengeluaran ASI pada hari-hari pertama setelah melahirkan menjadi kendala dalam pemberian ASI dini. Penurunan produksi ASI pada hari-hari pertama pasca melahirkan dapat disebabkan oleh kurangnya stimulasi hormon prolaktin dan oksitosin yang berperan penting dalam kelancaran produksi ASI.

Efektivitas pijat oksitosin dan pijat payudara lebih bermakna setelah melihat analisis umur, pendidikan, pekerjaan, dan paritas. Kemudian peneliti menyimpulkan bahwa produksi ASI ibu nifas berjalan lancar karena kombinasi pijat oksitosin dan pijat payudara. Dan hipotesis peneliti utama terbukti. Karena dengan melakukan kedua teknik tersebut, 
ibu nifas dapat mengatasi masalah menyusui yang muncul di hari-hari pertama kelahiran, seperti ASI tidak lancar atau ASI belum keluar. Dengan produksi ASI yang melimpah, cakupan pemberian ASI pada jam pertama persalinan bahkan pemberian ASI dapat meningkat.

Usia merupakan salah satu faktor yang dapat mempengaruhi produksi ASI. Ibu yang lebih muda akan menghasilkan ASI lebih banyak daripada ibu yang lebih tua. [8] Ibu yang lebih muda lebih cenderung memiliki ASI dibandingkan ibu yang lebih tua. [9] Ibu usia 1923 tahun pada umumnya dapat menghasilkan ASI yang cukup dibandingkan dengan ibu yang berusia 30-an. [10] Hasil penelitian menunjukkan bahwa proporsi ibu dengan produksi ASI lancar paling banyak terdapat pada kelompok umur di bawah 30 tahun.

ASI diproduksi sesuai kebutuhan bayi. Semakin sering bayi menghisap puting ibu maka akan terjadi reflek letdown yang menyebabkan produksi hormon oksitosin sehingga ASI dapat keluar. Perawatan nifas dengan kolaboratif care memungkinkan ibu menyusui bayinya sesering mungkin sesuai kebutuhan bayi.

Pendidikan dapat mempengaruhi kemampuan dan upaya orang tua dalam merawat dan menjaga kesehatan anak serta menyesuaikan dengan peran orang tua sehingga lebih mudah untuk mencapai sesuatu. [11] Keberhasilan menyusui tidak ditentukan oleh tingkat pendidikan ibu tetapi oleh informasi tentang menyusui yang diterima ibu pada waktu prenatal. Ternyata ibu nifas membutuhkan edukasi tentang menyusui pada masa prenatal, dan informasi yang diberikan harus konsisten dan realistis. Hasil penelitian juga menunjukkan bahwa ibu yang produksi ASI lancar sebagian besar berpendidikan rendah pada setiap pengukuran. [12]

Tingkat pendidikan seseorang tidak dapat dijadikan pedoman bahwa seseorang akan berhasil selama proses menyusui. Namun, informasi yang benar dan diterima tentang proses menyusui sebelumnya akan menentukan keberhasilan proses menyusui. Seseorang yang berpendidikan rendah tetapi mendapat informasi yang akurat tentang menyusui akan berhasil dalam proses menyusui. Pendidikan kesehatan tentang menyusui perlu diberikan kepada ibu selama kehamilan agar memiliki keyakinan bahwa ia akan berhasil dalam proses menyusui.

Ibu bekerja mempengaruhi produksi ASI meskipun ibu telah menjelaskan teknik menyusui. [13] Bekerja tidak ada alasan untuk menghentikan pemberian ASI eksklusif, padahal cuti melahirkan hanya 3 bulan. Dengan pengetahuan yang benar tentang ASI, alat pemeras ibu yang bekerja tetap dapat memberikan ASI Eksklusif. Meskipun responden belum kembali bekerja pada saat pendataan, ada kemungkinan ibu bekerja yang tidak memiliki pengetahuan cukup tentang menyusui merasa khawatir atau cemas terhadap produksi ASInya. Kondisi psikologis ibu sangat mempengaruhi produksi ASI. [8] Adanya fasilitas untuk ibu menyusui seperti ruang menyusui juga dapat menjadi faktor esensial dalam pemberian ASI. Ibu bekerja memiliki sikap positif terhadap ASI karena di tempat kerjanya terdapat booth menyusui. [14]

Ibu yang memiliki anak dalam penelitian ini memiliki proporsi produksi ASI yang lebih tinggi dibandingkan ibu yang belum pernah memiliki anak. Ibu yang memiliki anak menunjukkan produksi ASI yang lebih banyak dibandingkan ibu yang tidak pernah memiliki anak. Pada hari keempat pascapersalinan. Peningkatan jumlah paritas menyebabkan perubahan produksi ASI, meskipun tidak signifikan. Produksi ASI pada anak pertama adalah $580 \mathrm{ml} / 24$ jam. Anak kedua $654 \mathrm{ml} / 24$ jam; anak ketiga $602 \mathrm{ml} / 24$ jam; anak keempat $600 \mathrm{ml} / 24$ jam; anak kelima adalah $506 \mathrm{ml} / 24 \mathrm{jam}$. [15]

Ibu yang pernah menyusui memiliki hubungan yang positif dengan pemberian ASI dalam waktu satu jam setelah lahir dengan p-value $=0,001$. [16] Peluang ibu multipara untuk menyusui dalam waktu satu jam setelah melahirkan dua kali lebih besar $(\mathrm{OR}=2,16)$ dibandingkan ibu primipara. [17] Seorang ibu yang berhasil menyusui pada persalinan sebelumnya akan merasa lebih nyaman dan percaya diri untuk menyusui pada persalinan 
berikutnya. Bagi seorang ibu yang pernah melahirkan, kolostrum akan keluar lebih cepat, dan jumlahnya lebih banyak dibandingkan yang belum atau yang baru pertama kali melahirkan. [18]

Selama menyusui sebelumnya, pengalaman dan keyakinan ibu akan mempengaruhi perilaku ibu dalam proses menyusui selanjutnya. Jika ibu berhasil menyusui anak pertama, maka ibu akan lebih percaya diri saat menyusui anak kedua. Keyakinan ibu ini bisa merangsang keluarnya hormon oksitosin sehingga ASI bisa keluar dengan lancar.

\section{Kesimpulan}

[1] Ambarwati, E. R., \& Wulandari, D. (2010). Asuhan kebidanan nifas. Yogyakarta: Nuha Medika, 154.

[2] Cadwell, K., \& Turner-Maffei, C. (2011). Buku saku manajemen laktasi. Jakarta: EGC.

[3] UNICEF. (2013). Breastfeeding is the cheapest and most effective life-saver in history. UNICEF, New York.

[4] Fatimah, L. (2012). Hubungan Pemberian ASI Eksklusif dengan Kembalinya Menstruasi pada Ibu Menyusui di Desa Ngumpul, Jogoroto, Jombang. Prosiding Seminas, 1(2).

[5] Soetjiningsih, S. (2004). Tumbuh Kembang Remaja dan Permasalahannya. Sagung Seto. Jakarta, 320.

[6] Guyton, A. C., \& Hall, J. E. (2007). Buku Ajar Fisiologi Kedokteran.[diterjemahkan oleh Irawati, Ramadhani D, Indriyani F, Dany F, Nuryanto I, Riyanti SSP, Resmisari T, Suryono YJ]; editor, Rachman LY, Hartanto H, Novrianti A, Wulandari N. Jakarta: EGC.

[7] Roesli, U., \& Yohmi, E. (2009). Manajemen laktasi. Jakarta: IDAI.

[8] Biancuzzo, M. (2003). Breastfeeding the newborn: Clinical strategies for nurses. Mosby Incorporated.

[9] Suraatmaja, S. (2007). Aspek gizi air susu ibu. Soetjiningsih, Edi.

[10] Pudjiadi, S. (1999). Bayiku sayang: petunjuk bergambar untuk merawat bayi dan jawaban atas 62 pertanyaan yang mencemaskan. Fakultas kedokteran Universitas Indonesia.

[11] Friedman, M. M. (1998). Keperawatan Keluarga dan Praktek. Jakarta: Penerbit Buku Kedokteran EGC.

[12] Moore, E. R., \& Coty, M.-B. (2006). Prenatal and postpartum focus groups with primiparas: breastfeeding attitudes, support, barriers, self-efficacy, and intention. Journal of Pediatric Health Care, 20(1), 35-46.

[13] Suradi, R., \& Tobing, H. K. (2004). Manajemen laktasi. Jakarta: CV Sagung Seto.

[14] Suyes, K., Abrahams, S. W., \& Labbok, M. H. (2008). Breastfeeding in the workplace: Other employees' attitudes towards services for lactating mothers. International Breastfeeding Journal, 3(1), 25.

[15] Lovelady, C. A. (2005). Is maternal obesity a cause of poor lactation performance? Nutrition Reviews, 63(10), 352-355.

[16] Riva, E., Banderali, G., Agostoni, C., Silano, M., Radaelli, G., \& Giovannini, M. (1999). Factors associated with initiation and duration of breastfeeding in Italy. Acta Paediatrica, 88(4), 411-415. 
[17] Kools, E. J., Thijs, C., \& Vries, H. de. (2005). The behavioral determinants of breast-feeding in The Netherlands: predictors for the initiation of breastfeeding. Health Education \& Behavior, 32(6), 809-824.

[18] King, J. C. (2000). Determinants of maternal zinc status during pregnancy. The American Journal of Clinical Nutrition, 71(5), 1334S-1343S. 